Pym, A., \& Assis Rosa, A. (Eds.) (2012). New directions in translation studies/Novos rumos nos estudos da tradução. Special Issue of Anglo Saxonica 3.3. Lisbon: University of Lisbon Centre for English Studies. 394p.

Expectations do rise when one receives a volume of Anglo Saxonica entitled New Directions in Translation Studies/Novos Rumos nos Estudos da Tradução. And expectations are even higher when the guest editors present a quote without a citation in the first line of the introduction: "We need more visibility for Translation Studies in Portugal!" After all, with the greater bulk of Translation Studies publications stemming from English-speaking countries, a volume of articles produced in Portugal seems to announce that the "periphery" has also decided to speak up.

The word periphery here finds an echo in the theme of the VII Congress of the European Society for Translation Studies, namely Centres and Peripheries, held at the University of Mainz in Germersheim in late August of 2013. It is a sign of times, so it seems, that the guest editors state that that "at least was the cry as we thought we heard it" (p. 13) and although, they say, the threat is no longer there and "European Translation Studies has amply demonstrated its capacity to energize a significant part of the humanities" (p. 13), the guest editors "have responded nevertheless" (p. 13) by going "in search of Translation Studies in and around things Portuguese" (p. 13). The special issue of Anglo Saxonica 3.3 contains what they have found and I must admit that, after reading the volume, my first expectations were lowered and my reaction was a mixture of feelings, some of them good, others not quite so.

The volume starts with an introduction written by the guest editors, that is, Anthony Pym and Alexandra Assis Rosa (pp. 14-15). Pym and Rosa state that they "have gone in search of Translation Studies in and around things Portuguese" (p. 13) and divide their searches, and what they have found, into four sections: (1) Literary Translation (pp. 17227), Technical Translation (pp. 229-310), (3) Interpreting (pp. 311-332) and (4) Audiovisual Translation (pp. 333-384). At first glance, the 210 pages dedicated to literary translation seem to indicate that literary translation constitutes the focus of Portuguese-related investigations in Translation Studies. After all, there are only 81 pages dedicated to technical translation, 21 pages to interpreting, and 51 to audiovisual translation, comprising a total of 153 pages in a 392-page volume.

The first section on literary translation contains nine articles with disparate approaches and a focus on anthologizing and historiography, which helps to bring the articles together.

"Trusting translation" by João Ferreira Duarte (pp. 19-38) describes the historical contours of binary structures that have governed 
western translation discourse. The author claims that for centuries the metalanguage of translation has replicated polarities, such as St. Jerome's uerbum e uerbo vs. sensum de sensu, in an attempt to build trust on the presumption of equivalence. Using Anthony Giddens's sociology, Ferreira Duarte tries to show that the binary structures used in western translation discourse legitimize the equivalence pact and help to keep trust on a western definition of translation.

"Anthologizing Latin American literature: Swedish translative reimaginings of Latin America 1954-1998 and links to travel writing" by Cecilia Alvstad (pp. 41-68) revisits nine Swedish anthologies of Latin American literature published in the second half of the twentieth century. Alvstad analyses the discourse of blurbs and forewords to illustrate changing representations of Latin America and to identify links with travel writing in association with re-imaginings, which are typical of this type of genre.

"The intersection of Translation Studies and Anthology Studies" by Patricia Anne Odber de Baubeta (pp. 71-84) examines the symbiotic relationship between the activities of translating and anthologizing, arguing that without translation many anthologies would never be compiled. Highlighting the case of Portugal, Odber de Baubeta shows that the relationship between translating and anthologizing is a two-way avenue that helps to promote the canonization of foreign authors but also contributes to increasing the readership of Portuguese literature in other languages.

"José Paulo Paes: A pioneering Brazilian theoretician" by John Milton (pp. 87-100) examines the theoretical writings of the Brazilian poet, translator and essayist José Paulo Paes. In addition, this article discusses Paes's contribution to the growth of Translation Studies in Brazil. Milton argues that Paes introduced in his writings subjects and themes that would be taken up by other Brazilian translation scholars in later years.

"Translation and literature again: Recent approaches to an old issue" by Maria Eduarda Keating (pp. 103-126) presents an overview of the development of Translation Studies in Portugal over the last thirty years. She identifies three main currents based on the analysis of major Portuguese works published in this period: (1) a descriptive and polysystemic approach, (2) a postcolonial approach and (3) a view of translation that is specifically more literary and philosophical. In her analysis, Keating highlights the potential that she sees in the translation of literary texts to foster understanding in cultures and political practices entailed in intercultural relations.

"Under the sign of Janus: Reflections on authorship as liminality in translated literature" by Alexandra Lopes (pp. 129-156) discusses different alternatives to the use of paratexts in the history of literary translation. Among the several items in the paratextual apparatus, including postfaces, dedicatory epistles, glossaries, titles, intertitles, 
inscriptions and endnotes, Lopes argues that footnotes offer the clearest manifestation of the presence of the translator in the text and help to assert the translator's reading/rendering as well as to point to other reading possibilities.

"Translated and non-translated Spanish picaresque novels in defense of dominated languages" by Rita Bueno Maia (pp. 159-183) explores a historical example of how translations can work in defence of a dominated target language. Bueno Maia shows how Spanish picaresque novels contributed to the autonomy of the Spanish literary language against Italian and Latin, dominant languages in the sixteenth century. Her analysis also highlights how these literary products contributed to the defence of the Portuguese language later in the nineteenth century.

"The Translation of Great War American narratives in Portugal: The introduction of a new literary canon and the (re)definition of a cultural identity" by Maria Lin Moniz (pp. 187-203) focuses on the translation of two American novels to show their links to the political and social agendas of the 1920s and 1930s. Lin Moniz subsequently analyses the translations of these works made in the 1950s and 1960s, as part of a strategy of cultural planning, to argue that the existing political and social agendas promoted the introduction of a new canon, of a new literary style and of a new culture identity in Portugal.

"A Long and winding road: Mapping translated literature in $20^{\text {th }}$ century Portugal" by Alexandra Assis Rosa (pp. 207-227) describes the project of creating a database of bibliographical records for translated literature from 1930 to 2000. Assis Rosa also shows how this project developed into a more extensive search for other bibliographical records and she discusses the problems observed in such an attempt and the benefits resulting from the construction of the database. Finally, Assis Rosa outlines avenues for future bibliographical research related to intercultural literature in Portugal.

The second section on Technical Translation contains three articles with disparate approaches and, unfortunately, a lack of thematic cohesion to bring them together.

"Translating companies in Portugal" by Fernando Ferreira-Alves (pp. 233-263) surveys the Portuguese translation market from the point of view of language service providers. This article shows how some of the most important translation agencies operate in Portugal. As FerreiraAlves states, the survey provides new insights into market expectations and helps to build a better picture of the ideal language service provider in the Portuguese context.

"Footprints in the text: Assessing the impact of translation on the Portuguese historiographical discourse" by Karen Bennett (pp. 267-290) examines recent changes in writing styles in Portuguese and argues that the pressure exerted by translated texts upon historiographical discourse may be responsible for such changes. Bennett then discusses the impact of English historiographical texts in Portuguese translations and the 
influence that such texts may have on the writing styles of some younger Portuguese scholars.

"A brief history of postediting and of research on postediting" by Ignacio Garcia (pp. 293-310) reviews the history of post-editing and, by exploring the Machine Translation Archives, shows how industry, practitioners and scholars dealt with post-editing from 1950 to 1999. Garcia mentions that topics and methodologies identified in his review can help researchers to focus on their enquiries and to contribute to fostering innovative research in a web-enabled world.

The third section on Interpreting consists of a sole article and is thematically distant from the previous and following sections.

"Conference interpreting in Brazil: A brief historical overview and some future trends" by Reynaldo José Pagura (pp. 315-332) provides an overview of conference interpreting in Brazil, from its beginnings in the 1940 s to the state of the market in the twenty-first century. Most information in the article stems from interviews carried out by the author with renowned conference interpreters working in Brazil. It shows how conference interpreting has grown in Brazil and it claims that conference interpreting now follows the general tendencies observed in the international scene.

The fourth section on Audiovisual Translation contains two articles related to issues pertaining the Portuguese context.

"Audiovisual translation in Portugal: The story so far" by Sara Ramos Pinto (pp. 337-363) describes developments in the field of audiovisual translation over the last two decades and presents an overview of the different audiovisual translation modes available, with a special focus on the situation in Portugal. Ramos Pinto shows that the widening of scope in the field posits new challenges and, consequently, requires new and more advanced research methods.

"Audiovisual translation for accessible media in Portugal" by Josélia Neves (pp. 367-384) discusses the issue of social inclusion mediated by accessible communication in Portugal. Neves claims that accessible communication goes hand in hand with audiovisual translation and that the field has witnessed a growing interest in subjects such as subtitling for the deaf and hard of hearing, sign language interpreting, and audio description. However, as Neves argues, the situation in Portugal seems to be far from being on the way to true inclusion.

The volume concludes with a section entitled Notes on Guest Editors and Contributors, which provides the readers with background information about the authors and editors.

A great deal of work has been put into this volume. The editing is meticulous and much care has been given to formatting and proofreading. However, as the guest editors stated in the introduction, the volume of Anglo Saxonica 3.3. "is not a sample of Portuguese Translation Studies; it is more like a few slices from a Translation Studies cake, where Portugal is a particularly juicy layer" (p. 14). With regard to the structure of the 
volume, some of the 'cake layers' are thicker than others and a few are so thin that the overviews that they present lack amplitude.

\section{Fabio Alves}

Federal University of Minas Gerais, Brazil

fabio-alves@ufmg.br 